\title{
Productivity and Offshoring Innovative Activities
}

\author{
Saleh S. Tabrizy ${ }^{* \dagger}$ \\ The University of Oklahoma \\ Department of Economics
}

\footnotetext{
*I am grateful to Rebecca Neumann for her supervision. I am also grateful to two anonymous referees, Kundan Kishor, and Suyong Song for their helpful comments. I would like to thank Bruegel Institute, and especially Carlo Altomonte, for providing the data set and further support. I remain responsible for any shortcomings and errors.

${ }^{\dagger}$ Mail: The University of Oklahoma, 308 Cate Center Drive, CCD1, No. 325, Norman, OK, 73019; Email: tabrizy@ou.edu; Phone: (405)325-3614.
} 


\begin{abstract}
Recent studies suggest that firms may gain from global sourcing of innovative activities. Yet, only a small number of firms offshore their R\&D, design, and engineering tasks. To explain this selection pattern, this paper examines the heterogeneity in total factor productivity among a large group of European firms. The results suggest that those firms that offshore their innovative activities tend to be more productive than domestic firms, exporters, and other multinational corporations. This finding implies that firms with superior productivity are more likely to exploit the global task distribution in innovative activities, which may provide an explanation for why such low participation is observed in the data.
\end{abstract}

Keywords: Total Factor Productivity; Multinational Corporations; Offshoring R\&D 


\section{Introduction}

The organization of innovative activities has for long been an important subject in the Economics of Innovation. Some of the key questions in this line of research relate to the choices that firms make with regard to performing their innovative tasks in-house versus distributing them among other parties. Those parties, who may or may not be affiliated with the firms, are either located in the same country where the main firm is located, or they are located in a foreign country. In fact, distributing innovative activities among foreign parties has recently become an increasing trend. For example, a recent report by National Science Board (2016, Ch. 4) suggests that in 2012 the amount of R\&D performed by the affiliates of foreign multinationals in the US ( $\$ 48$ billion) was about $16 \%$ of the entire R\&D performed by businesses in the US ( $\$ 302.3$ billion). In 1997, this share was about $11 \%$. This report also suggests that European multinationals play an important role in global sourcing of innovative activities. More than half of the R\&D performed by the affiliates of foreign multinationals in the US in 2012 were allocated by firms owned by European parent companies that are based in Switzerland (20\%), the UK (14\%), France (14\%), and Germany (12\%).

When it comes to performing innovative activities offshore, previous research suggest that firms are motivated by demand- and supply-driven incentives. On the demand side, firms are more likely to be able to adapt their products to the preferences of their foreign customers when they perform their innovative activities offshore (Cantwell and Mudambi 2005). As for the supply-driven incentives, firms are likely to lower the cost of their innovative activities (Lai, Riezman, and Wang 2009). They may also be able to take advantage of potential R\&D spillovers (Feinberg and Gupta 2004), expertise (MartinezNoya, Garcia-Canal, and Guillen 2012), and qualified personnel (Lewin, Massini, and Peeters 2009) in foreign countries. ${ }^{1}$

Previous studies also suggest that firms gain from global sourcing of their innovative activities. These gains are evident when measures of firms' performance, such as return on equity and return on sale, are examined (Ceci and Masciarelli 2010). They are also evident when measures of firms' innovation output are examined. Notably, Kotabe et al.

\footnotetext{
${ }^{1}$ See Jabbour and Zuniga (2016) and Nieto and Rodrìguez (2011) for a detailed survey of the underlying motives behind the offshoring of innovation.
} 
(2007) find that greater international knowledge content contributes to the innovation output. Also, Nieto and Rodrìguez (2011) suggest that the offshoring of R\&D tasks may positively affect innovative performance of the firms, as measured by the propensity to innovate. Along with the gains in terms of the extensive margin of innovation output (i.e., whether a firm innovates), Tabrizy (2015) suggests that the offshoring of innovative tasks (e.g., R\&D, design, and engineering services) may also contribute to the intensive margin of innovation, as measured by the share of innovative product sales in total turnover. ${ }^{2}$

Despite the above motives and potential gains, only a small number of firms offshore their innovative tasks. For example, Jabbour and Zuinga (2016), who examine a survey compiled by the French Statistics Office for Research and Innovation, find that only 12\% of R\&D performers in France are involved in international R\&D sourcing. This low participation rate may be caused by some intellectual property concerns (e.g., Lai et al. 2009 and Garcìa-Vega and Huergo 2011), which can be explained using property right models of firm boundaries. The model developed by Antràs (2003), for instance, suggests that the transaction cost of performing innovative activities offshore could be relatively high at the equilibrium. ${ }^{3}$ Thus, firms with offshore innovative efforts are more likely to internalize those activities via foreign direct investments (henceforth, FDI), so they can manage the intellectual property risks. Also, given the predictions in Antràs and Helpman (2004), firms that are involved in FDI are expected to be very productive. These predictions imply that offshoring $\mathrm{R} \& \mathrm{D}$, design, and engineering services are expected to be done via FDI and by the most productive Multinational Corporations (henceforth, MNCs). Tabrizy (2015, pp. 310-313) provides detailed information, suggesting that the majority of European MNCs that offshore their innovative activities tend to rely on FDI. Yet, the superior productivity of MNCs with offshore innovative activities had remained unexplored.

\footnotetext{
2 Since greater innovative product sales may contribute to productivity (Crèpon, Duguet, and Mairessec 1998) and profitability (Roberts 1999), it is important to examine the gains in terms of the intensive margin of innovation output as well as the extensive margin.

3 This is not an explicit finding in Antràs (2003) since he broadly examines capital- vs. labor-intensive tasks. Yet, it provides valuable insight into the possibility of relatively high cost for the offshoring of innovative activities. These tasks typically require a great amount of investment in R\&D equipment and highly skilled labor force, and they are expected to be performed at the headquarters. Offshoring those activities is, therefore, expected to be very costly.
} 
Fortunately, the relationship between firms' productivity and their international activities has been widely studied in International Economics. It is now well established that the most productive firms are more likely to partake in international activities such as exporting (Melitz 2003), FDI (Helpman, Melitz, and Yeaple 2004), and other forms of global sourcing (Antràs and Helpman 2004). ${ }^{4}$ This selection enables us to explain some interesting patterns that are observed in the data. In particular, it helps us understand why only a small number of firms partake in international activities such as exporting, importing, and global sourcing of productive and innovative tasks.

In this paper, I examine the superior productivity of the firms that exploit the global task distribution in innovative activities. The working hypothesis of this paper is as follows: Those MNCs that offshore their innovative tasks are more productive than $M N C s$ that offshore their non-innovative tasks. Also, since MNCs are in general more productive, MNCs with offshore innovative activities are expected to be more productive than exporters as well as firms that only serve the domestic markets.

Employing a recent European firm-level survey, this paper contributes to the literature by estimating the productivity premium of the firms that are actively involved in offshoring different types of tasks, including the production of finished products, the production of semi-finished products/components, and R\&D, design, and engineering services. I employ kernel density estimations, along with linear and ordered Probit estimations to test whether those firms that offshore their R\&D, design, and engineering services are more productive than others. The results suggest that compared to other firms in the full sample and the sub-sample of MNCs, those firms that offshore their innovative activities enjoy greater productivity. This finding may provide an answer to the puzzle above: though MNCs gain from the offshoring of innovation, they must be very productive in order to be able to offshore their innovative activities, which is why only a small number of MNCs are able to successfully partake in the global sourcing of innovative tasks.

This empirical exercise does not address any causality questions. To examine the causality relationship, one needs to design a randomized trial or to use some exogenous

\footnotetext{
${ }^{4}$ See Bernard et al. (2012) for a recent survey of empirical findings on firm heterogeneity in international trade.
} 
variations that can predict whether a firm distributes it innovative tasks across the globe. Unfortunately, I do not have access to any of the above. Nonetheless, in this paper, I am able to explore some interesting patterns that appear in the data by estimating the productivity premium of those MNCs that distribute their innovative tasks abroad.

In what follows, previous empirical studies are briefly reviewed in Section 2. The data are discussed in Section 3. The empirical analyses and results are presented in Section 4. Section 5 concludes.

\section{Background}

By the late 1980s, the offshoring of innovation was already widespread (Cantwell 1995). This motivated a wide range of studies in International Business, the Economics of Innovation, and International Economics. Though there are some earlier research on this topic (e.g., Ronstadt 1977; Mansfield, Teece, and Romeo 1979; Lall 1979), most of the contributions to this literature are made as of early 1990s (e.g., Pearce and Singh 1992; Granstrand, Håkansson, and Sjölander 1992; Dunning 1994). ${ }^{5}$ Since then, this literature has grown significantly. The most recent studies explore, at least, four areas of research: the determinants of global sourcing of innovative activities (e.g., Lewin et al. 2009; Garcìa-Vega and Huergo 2011; Jensen and Pedersen 2012; Jabbour and Zuniga 2016; Danguy 2016; Tamayo and Huergo 2016), the potential gains (e.g., Kotabe et al. 2007; Ceci and Masciarelli 2010; Nieto and Rodrìguez 2011; Castellani and Pieri 2013; Tabrizy 2015), the organizational aspects (e.g., Bardhan 2006; Lai et al. 2009; Grimaldi et al. 2010; Martinez-Noya et al. 2012; Bertrand and Mol 2013), and the emerging global geography of innovation (e.g., Fifarek and Veloso 2010 and D'Agostino, Laursen, and Santangelo 2013).

Against this background, this study contributes to two lines of research. By focusing on firms' productivity, it improves our understanding of the determinants of global sourcing of innovative activities. It also provides a detailed description of the productivity requirements for offshoring different types of tasks, including R\&D, design, and engineering tasks.

\footnotetext{
${ }^{5}$ Focusing on the crucial role of MNCs in the global distribution of innovative tasks, Narula and Zanfei (2005) review some of those contributions.
} 
There are two recent studies that incorporate the variations in productivity into their theoretical and empirical models of offshoring innovation. Garcì-Vega and Huergo (2011) introduce a model in which firms with heterogeneous productivity may outsource their innovative activities to domestic or foreign parties. They suggest that probability of outsourcing R\&D internationally is greater for exporters, who are more productive than non-exporters. They also examine how financial constraints and lack of information may affect the probability of this international sourcing. Motivated by their theoretical propositions, they use a sample of Spanish firms, and employ selected measures of absorptive capacity (e.g., continuous R\&D engagements, R\&D employments, size, etc.) as independent variables that control for variations in productivity. Their estimation results suggest that, in general, firms with greater absorptive capacity are more likely to outsource their R\&D internationally. ${ }^{6}$ Jabbour and Zuniga (2016), who examine a sample of French firms, also employ a measure of technology gap as an independent variable that controls for variations in productivity. They measure this gap by comparing the estimated total factor productivity of a given firm with the productivity of the leader in the sector. Their estimation results suggest that firms with smaller technology gap, whose productivity is relatively closer to that of the leading firm in the sector, are more likely to offshore their R\&D. Holding all else constant, therefore, these two studies suggest that firms with greater absorptive capacity and productivity are more likely to offshore their innovative activities. $^{7}$

This study contributes to the above line of research in two ways. First, I employ an estimated measure of total factor productivity. Employing this measure, which is also used in Jabbour and Zuniga (2016), I am able to add upon the findings reported in Garcìa-Vega and Huergo (2011). Unlike these studies, however, I follow Altomonte, Aquilante, and Ottaviano (2012, Ch. 4) and employ the estimated productivity as dependent variable, rather than control covariate, to focus on productivity premium. Second, I use a sample which is representative of all manufacturing firms in Europe

\footnotetext{
${ }^{6}$ Martinez-Noya et al. (2012) report similar findings. They suggest that firms with more technological resources and capabilities, measured by R\&D intensity and number of patents, are more likely to offshore their R\&D.

${ }^{7}$ Measures of absorptive capacity and productivity are employed only as control covariates in these studies, and it is difficult to infer any causal relationships from the reported results.
} 
(innovating and non-innovating), rather than a sample which is only representative of innovating firms. ${ }^{8}$

A number of empirical studies also examine the superior productivity of international firms. This paper relates to three of them, in which the productivity of the firms that integrate (domestically or abroad) and/or outsource (domestically or abroad) part of their productive activities are examined. ${ }^{9}$ In a sample of Italian manufacturing firms, Federico (2010) finds that the most productive firms tend to integrate abroad, and that the firms with medium-high productivity integrate domestically. He also finds that the firms with medium-low productivity choose foreign outsourcing, and that the least productive firms outsource domestically. Unlike the prediction in Antràs and Helpman (2004), his findings imply that, regardless of the destination of productive activities, firms that integrate (either abroad or domestically) are more productive than firms that outsource (either abroad or domestically). Also, Kohler and Smolka (2012) examine a sample of Spanish firms. They verify that global sourcing requires greater productivity. They also find that, in general, integration requires greater productivity than outsourcing. Lastly, in a sample of Japanese international firms, Tomiura (2007) finds that the most productive firms tend to integrate offshore, while the less productive ones tend to outsource abroad. He also finds that the least productive firms remain at home. This pattern is well in line with the sorting in Antràs and Helpman (2004).

This study contributes to the above line of research by taking into account different types of tasks that may be performed offshore. The above studies do not distinguish between productivity requirements for the offshoring of different types of tasks (e.g., productive vs. innovative), nor do they explicitly examine the productivity requirement for the offshoring of innovative tasks. However, the survey used in this study enables me to compare the superior productivity of firms with offshore innovative activities to those

\footnotetext{
8 Garcìa-Vega and Huergo (2011) employ a sample of innovating firms in Spain, using Panel de Innovaciòn Tecnologica. Jabbour and Zuniga (2016) employ another sample of innovating firms in France, using Enquête Recherche et Developement.

${ }^{9}$ To be clear, I need to define some of the terms that I use in this paper: Firms "integrate" their productive activities into another firm once they distribute those tasks across affiliated parties (e.g., foreign or domestic M\&A). They "outsource" those activities to another firm once they distribute them across unaffiliated parties (e.g., arms length agreements with foreign or domestic firms). Given these two definitions, "offshoring" would generally refer to a case in which the second party is located in a foreign country, no matter if it is affiliated or not. When the foreign party is affiliated with the firm, it is usually called "captive offshoring." When it is not affiliated, it is called "offshore outsouring."
} 
firms that offshore different types of productive activities as well as exporters and domestic firms.

\section{Data}

Firm-level observations used in this study come from the European Firms in a Global Economy (EFIGE) survey. ${ }^{10}$ The main focus of this survey is on international activities, but it also provides further information about the structure of the firms, their workforce, investments, innovative activities, markets, and finances. The data set includes a wellstratified sample of about 15,000 manufacturing firms in 7 European countries. ${ }^{11}$ For some of these firms, the survey in use provides the estimated Levinsohn and Petrin (2003) total factor productivity (henceforth, TFP). I make use of this sub-sample, which includes 7,435 firms from Austria (25 firms), France (1,605 firms), Germany (579 firms), Hungary (179 firms), Italy (2,243 firms), Spain (2,410 firms), and the UK (394 firms). Altomonte et al. (2012) suggest that, compared to the full sample, this sub-sample does not show any bias in terms of representation by category of firms (domestic vs. active abroad). ${ }^{12}$

The data were collected in 2010. Though some of the questions are about the averages from 2007 to 2009, most of them reflect the information for the last available budget year: 2008. Thus, I am only able to make cross-sectional comparisons in this study.

The TFP measure in use is estimated via firms' value added, deflated by the industryspecific price indicies. This measure is part of the residual of an estimated Cobb-Douglas production function in which the number of employees, the value of tangible fixed assets, and the value of intermediate inputs are employed to predict the value added for any given firm. ${ }^{13}$

\footnotetext{
${ }^{10}$ The EFIGE survey has been conducted by Bruegel, a European think tank, along with seven other partners, and it is supported by the Directorate General Research of the European Commission.

11 The stratification process is described in Barba Navaretti et al. (2011, pp. 57-60). The resulting sample includes 14,759 firms from Austria (443 firms), France (2,973 firms), Germany (2,935 firms), Hungary (488 firms), Italy (3,021 firms), Spain (2,832 firms), and the UK (2,067 firms).

12 See Tables 2 and 3 in Altomonte et al. (2012) for more details.

${ }^{13}$ Altomonte et al. (2012) provide more information on the estimation procedure (pp. 59-60) and the validation of the measure (pp. 21-26).
} 
Also, this survey provides detailed information about the type of offshore activities in which firms are involved. In particular, one can observe whether any given MNC offshores the production of its finished products, the production of its semi-finished products/components, and/or its R\&D, design, and engineering activities. These activities are performed offshore either through FDI or contracts and arms length agreements.

This survey provides an ideal dataset for this empirical exercise since one has access to an unbiased estimation of firm-level TFP as well as detailed information about the type of tasks that are performed offshore.

As illustrated in Figure 1, about 6.24\% of the firms in the sample (464 firms) offshore the production of their finished products abroad (either via FDI or contracts and arms length agreements); about $4.28 \%$ (318 firms) offshore the production of their semifinished products/components; and only about $1.28 \%$ (95 firms) offshore their R\&D, design, and engineering activities abroad. Interestingly enough, the majority of MNCs that offshore their innovative tasks are also involved in other offshore activities: 77 firms offshore the production of their finished products, and 61 firms offshore the production of their semi-finished products/components. Further, there are 50 firms that are involved in all three activities. On average, those 50 firms are more productive than other MNCs. The mean of the estimated TFP measure for those firms is about 0.33 (with standard deviation of 0.52), while the same mean for other MNCs is about 0.05 (with standard deviation of $0.66) .^{14}$

This survey also provides for a wide range of control covariates. In what follows, I control for the variations in the TFP across countries and sectors using a vector of indicator variables. Firms in this survey are scattered around 7 European countries and 11 industries. Though the country of incorporation is available, it is impossible to identify the industry in which a given firm is involved. In fact, a randomized industry identifier is used in this survey to keep the data confidential. ${ }^{15}$

\footnotetext{
${ }^{14}$ One may safely reject the null hypothesis for the equality of the above means, and accept the alternative that the average productivity for the group of firms that are involved in all three activities is greater than the average productivity for the other MNCs ( $\mathrm{p}$-value $=0.04 \%$ ).

15 In email correspondence, one of the research fellows at Bruegel provided a list of industries that are included in this survey. However, the randomized industry identifiers for these industries remain unknown. The industries include: Manufacture of Basic Metals and Fabricated Metal Products; Manufacture of Food Product, Beverage, and Tobacco; Manufacture of Rubber and Plastic Products; Manufacture of Textiles and Textile Products, plus Manufacture of Pulp, Paper, and Paper Products (Publishing And Printing);
} 
I also control for exporting and innovative activities. It is well-established that exporters and R\&D performers are more productive than non-exporters and non-R\&D firms, respectively. Thus, I employ an export status dummy along with a R\&D performance status dummy as control covariates. For a given firm the export status dummy is set to be equal to one when the amount of exports is equal or greater than $10 \%$ of the annual turnover in 2008, and zero otherwise. About $43 \%$ of firms in the sample (3,211 firms) are identified as exporters. Also, for a given firm the R\&D performance status dummy is set to be equal to one when, on average, the amount of R\&D investments in 2007, 2008, and 2009 is greater or equal to $2 \%$ of the annual turnovers, and zero otherwise. About $40 \%$ of firms in the sample (2,967 firms) are identified as R\&D performers.

Lastly, I control for an ordinal size measure, which is based on the firms' annual turnover. This measure is useful to control for some unobservable size-specific variations that cannot be controlled for in cross-section estimations. The ordinal size measure is based on the annual turnover of the firms in 2008. The turnover categories include: less than 1 million euros, between 1 and 2, 2 and 10,10 and 15, 15 and 50, 50 and 250, or more than 250 million euros. The majority of firms in the survey $(43.47 \%)$ have reported an annual turnover between 2 and 10 million euros. Also, the annual turnover of about $20 \%$ of the firms is between 1 and 2 million euros. For about $12 \%$ of the firms this figure is between 15 and 50 million euros. Less than $25 \%$ of the sample belong to the other four turnover categories combined.

As summarized in Table 1, large firms (with annual turnover greater than 15 million euros in 2008) make up for a significant share of firms that are involved in global sourcing. In fact, about half of the firms that offshore the production of their finished products or semi-finished products/components are large. Also, when it comes to global sourcing of innovative tasks, $72 \%$ of the firms that offshore their R\&D, design, and engineering activities are large, which may be an indicator of their superior productivity.

Manufacture of Leather and Leather Products, plus Manufacture of Other Non Metallic Mineral Product, plus Manufacture of Electrical and Optical Equipment; Manufacture of Chemicals, Chemical Products, and Man-Made Fibres; Manufacture of Transport Equipment; Manufacture of Wood and Wood Products; Manufacturing N.E.C.; Manufacture of Machine and Equipment N.E.C.; and Sector No. 9. Since a very small number of firms are involved in Sector No. 9, no information could be provided about the type of activities in that sector. 


\section{Empirical Analyses}

In this section, I first employ a univariate kernel density estimation (henceforth, KDE) for the distribution of TFP among the MNCs that are involved in different types of offshore activities (Section 4.1). Given the estimated kernel densities, I employ linear and ordered Probit estimations to test the working hypothesis that MNCs with offshore innovative activities are more productive than other MNCs, exporters, and domestic firms (Section 4.2). I then report the regression results (Section 4.3). I conclude this section with a brief discussion of competing theories in light of the empirical findings of this paper (Section 4.4). ${ }^{16}$

\subsection{Kernel Density Estimation}

Figure 2 plots the KDE for the distribution of TFP among the firms that have performed the following tasks offshore: the production of finished products, the production of semifinished products/components, or R\&D, design, and engineering activities. ${ }^{17}$ As indicated earlier, these activities are not mutually exclusive. For instance, there are 50 firms in the sample that partake in all three of them. To make a better comparison, Figure 2 also plots the KDE for the distribution of TFP among the firms with no FDI or contracts and arms length agreements.

For a given group of firms, the estimated $\mathrm{KDE}$ is employed to identify the probability that firms' productivity is greater than a given TFP level. Among MNCs, the estimated densities suggest that the probability that firms' productivity is greater than a given TFP level is higher among firms with offshore innovative activities compared to those with offshore productive activities, including the production of finished products or semifinished products/components. This pattern implies that MNCs that offshore their R\&D, design, and engineering activities are more productive than MNCs that offshore their productive activities. It also appears that firms that offshore the production of their finished products are more productive than firms that offshore the production of their

\footnotetext{
${ }^{16}$ I am grateful to an anonymous referee, who suggested that I add this discussion to the manuscript.

17 Altomonte et al. (2012) provide some illustrations of kernel densities for different types of international activities such as exporting and importing. They also take into account some of the activities that are related to global sourcing. By looking at different types of tasks that are performed offshore, this paper provides a detailed picture of the productivity differences across the firms that are involved in different types of global sourcing.
} 
semi-finished products/components. ${ }^{18}$ Lastly, regardless of the type of activity performed offshore, MNCs are more productive than firms with no FDI or contracts and arms length agreements.

\subsection{Regression}

The above KDE results form the working hypothesis for the following regression analyses: Those MNCs that offshore their innovative tasks are more productive than MNCs that offshore their non-innovative tasks. Those MNCs are also more productive than exporters as well as firms that only serve the domestic markets. To test this hypothesis, I first employ the following regression function:

$$
E\left[\operatorname{TFP}_{i} \mid \operatorname{Ornd}_{i}, X_{i}\right\}=\alpha_{1} \operatorname{Ornd}_{i}+X_{i}^{\prime} \beta_{1}+E\left[\varepsilon_{i} \mid \operatorname{Ornd}_{i}, X_{i}\right]
$$

where $T F P_{i}$ is either the residual of a Cobb-Douglas production function for firm $i$, estimated using the Levinsohn and Petrin (2003) approach, or it is the TFP decile to which $T F P_{i}$ belongs. I use linear techniques when I employ the TFP measures directly, and I use ordered Probit techniques when I employ the deciles on the left-hand side. $\operatorname{Ornd}_{i}$ is a dummy variable, which takes value one when firm $i$ performs its $\mathrm{R} \& \mathrm{D}$, design, and engineering activities offshore, and zero otherwise. $X_{i}$ is a vector of control covariates, including an exporter status dummy, a R\&D performance status dummy, and a set of ordinal size dummies. Further, this vector includes a set of sector and country dummies. This regression function also includes a constant term.

I estimate the parameters of the above model (Equation 1) in the full sample as well as the sub-sample of MNCs. The working hypothesis implies that $\alpha_{l}$ is positive and statistically significant.

The model given by Equation 1 can also be presented differently. For this purpose, I define a dummy variable, $O \operatorname{fin}_{i}$, which takes value one when firm $i$ does not offshore its innovative activities, yet it produces some finished products offshore. Ofin $i$ is zero otherwise. I define another dummy variable, $\mathrm{Osem}_{i}$, which takes value one when firm $i$

\footnotetext{
${ }^{18}$ Since the main focus of this paper is on global sourcing of innovative activities, I do not explore the difference in productivity between MNCs that offshore the production of their finished products and MNCs that offshore the production of their semi-finished products/components. Nonetheless, the above KDE results may be taken as a preliminary evidence for the superior productivity of the former group.
} 
does not offshore its innovative activities or the production of its finished products, yet it produces some semi-finished products/components offshore. Osem is zero otherwise. There are also $50 \mathrm{MNCs}$ for which the type of offshore activities are unknown. I define a dummy variable, Other $_{i}$, for those firms. ${ }^{19} X_{i}$ being the same as given in Equation 1, the alternative regression function is as follows:

$$
\begin{aligned}
& E\left[\text { TFP }_{i} \mid \text { Ofin }_{i}, \text { Osem }_{i}, \text { Other }_{i}, X_{i}\right\}= \\
& \alpha_{21} \text { Ofin }_{i}+\alpha_{22} \text { Osem }_{i}+\alpha_{23} \text { Other }_{i}+X_{i}^{\prime} \beta_{2}+E\left[\varepsilon_{i} \mid \text { Ofin }_{i}, \text { Osem }_{i}, \text { Other }_{i}, X_{i}\right]
\end{aligned}
$$

I estimate the parameters of the above model (Equation 2) only in the sub-sample of MNCs, which enables me to compare the productivity of MNCs that perform (part of) their innovative activities (and possibly other types of productive activities) offshore with those that produce (part of) their finished products (and possibly their semi-finished products/components) offshore and also with those that only produce (part of) their semifinished products/components offshore. Though this is a slightly different regression function, the results are expected to be quite close to the estimation results for Equation 1. The working hypothesis implies that $\alpha_{21}$ and $\alpha_{22}$ are negative and statistically significant. $^{20}$

\subsection{Results}

Regression results confirm the pattern that emerges in the KDE plots: Conditional upon a wide range of covariates, those MNCs that offshore their innovative activities are more productive than other firms in the full sample and the sub-sample of MNCs. Table 2 offers more details.

The linear and ordered Probit results for the full sample estimations are reported in columns $I-I$ and $I I-I$ in Table 2, respectively. The results are quite predictable. Regardless of the types of activities that are performed offshore, MNCs are expected to be more productive than other firms. In fact, the estimation results verify this: Compared

\footnotetext{
19 Those 50 MNCs are not included in Figure 1.

20 Since I do not know the type of offshore activities in which the firms in Other category are involved, I do not have any priors for the sign of $\alpha_{23}$.
} 
to other firms, including exporters and domestic firms, those MNCs that offshore their innovative activities are more productive.

As for the control covariates, the estimated coefficient for exporter status dummy is statistically not different from zero, while the estimated coefficient for R\&D performance dummy is positive and statistically significant. Also, compared to small firms (with less than 1 million euros of turnover in 2008), larger firms are more productive. As annual turnover increases, the magnitude of correlation between ordinal size measures and TFP increases while the standard deviations remain almost intact. ${ }^{21}$

Since I control for ordinal size measures, the insignificant correlation between exporting activities and measures of TFP may not be striking. What is interesting, however, is the significant correlation between R\&D performance and TFP. The results suggests that $R \& D$ performers are significantly more productive than non-R\&D firms even after I control for the firms' size and other covariates.

As indicated in Section 4.2, I do not know the precise type of activities that are offshored by $50 \mathrm{MNCs}$ in this sample. To make sure that the results are not driven by those MNCs, I drop them from the sample, and re-estimate the parameters of interest. ${ }^{22}$ The results remain intact. Columns $I-2$ and $I I-2$ in Table 2 offer more details.

The results for the sub-sample of MNCs are more interesting: Compared to other MNCs who do not perform any innovative activities abroad, those MNCs that offshore their R\&D, design, and engineering activities are more productive. The linear and ordered Probit results, reported in columns $I-1$ and $I I-1$ in Table 3, are strong evidence of the superior productivity among the MNCs with offshore innovative efforts. In those estimations, the control groups are the other MNCs in the sample. Some of those MNCs in the control group offshore the production of their finished products or semi-finished products/components, and a minority of them (50 firms) are involved in other types of offshore activities that are unknown to me. The estimation results suggest that there exists a positive and significant correlation between the offshoring of innovative activities and the TFP measures. To illustrate this correlation, Figure 3 plots the estimated magnitude of

\footnotetext{
${ }^{21}$ For instance, one can safely reject the null hypothesis of the equality of estimated coefficients for ordinal size measures when the base-line results, reported in column I-1, are used. Detailed test results available upon request.

22 I am grateful to an anonymous referee, who raised this point.
} 
the productivity premium of MNCs with offshore innovative activities over other MNCs. The estimated magnitudes are based on the marginal effects of the ordered Probit estimation reported in column $I I-1$ in Table 3. Those MNCs that offshore their innovative activities are about $7.7 \%$ more likely to belong to the 10th decile of the TFP distribution. They are also about $4.4 \%$ more likely to belong to the 9 th decile of the TFP distribution. ${ }^{23}$ Compared to other MNCs, therefore, the results suggest that those MNCs that offshore their innovative activities are likely to be more productive.

As for the control covariates, the estimated coefficients for exporter and R\&D performer status dummies are statistically not different from zero, which may be the consequence of controlling for size. Also, a cross-sectional comparison among MNCs suggests that larger MNCs appear to be more productive. Like above, with an increase in annual turnover, the correlations between ordinal size measures and TFP measures increase.

I also drop those MNCs for which the type of off-shore activities are unknown, and re-estimate the parameters of interest to make sure that the results are not sensitive. The results remain intact again. Columns $I-2$ and $I I-2$ in Table 3 offer more details.

The above results can also be presented in a slightly different way, as given by Equation 2, in which the control group is made of the MNCs that offshore their innovative activities. The linear and ordered Probit results, reported in columns $I-1$ and II-1 in Table 4, suggest that those MNCs that do not partake in global sourcing of innovative tasks, for which Ofin, Osem, or Other are equal to one, are less productive than MNCs with offshore innovative activities. The estimated coefficients for control covariates are similar to the estimations that are reported in Table 3. Also, excluding the MNCs for which the precise type of offshore activities are unknown does not change the results (columns $I-2$ and $I I-2$ in Table 4 ).

\subsection{Discussion}

The underlying question in this empirical assessment relates to the governance of innovative activities in open economies. The above evidence suggest that only a small number of very productive firms are able to offshore their R\&D, design, and engineering

${ }^{23}$ The estimated marginal effects for each decile, as given by the solid line in Figure 3, add up to zero. Detailed estimations of the cut-off coeficients available upon request. 
activities. These firms are more productive than other MNCs that only offshore their productive activities. Previous studies also suggest that, when it comes to international sourcing of innovation, captive offshoring is more common than offshore outsourcing (Tabrizy 2015), and it is more effective (Nieto and Rodrìguez 2011).

These findings support the theoretical proposition that the most productive firms are likely to engage in global sourcing (Helpman, Melitz, and Yeaple 2004). They also support the proposition that captive offshoring via FDI requires greater productivity than offshore outsourcing (Antràs and Helpman 2004). Yet, the implications of these findings go beyond these propositions, as they point out to the differences that may exist in productivity requirements for offshoring different types of tasks (e.g., productive vs. innovative). When it comes to productive activities, Grossman, Helpman, and Szeidl (2006) offer a theoretical framework that accommodates varying productivity requirements for the offshoring of activities that relate to employing intermediate inputs versus assembly. ${ }^{24}$ To the best of my knowledge, however, there is no general equilibrium model that incorporates the differences in productivity requirements for the offshoring of activities that relate to production versus innovation. ${ }^{25}$ Such model could be based on the greater cost of offshoring innovative activities due to potential intellectual property risks. At relatively high levels of intellectual property risks, only the most productive firms can afford to perform their innovative tasks offshore. Firms, in such model, should be productive enough to partake in global sourcing, but they should be very productive to partake in global sourcing of their innovative tasks. Better intellectual property protection may lower the cost of this particular type of offshoring, which in turn leads more firms to offshore their innovative tasks.

\footnotetext{
${ }^{24}$ With relatively low fixed cost of captive offshoring in intermediate activities, their model suggest that the least productive firms may engage in FDI in intermediates, while the rest of the firms may engage in FDI in intermediates and assembly. However, a different sorting may emerge following an increase in the fixed cost of captive offshoring in intermediate activities: firms with relatively low levels of productivity do not continue with their FDI in intermediates, while firms with greater productivity continue with their FDI in intermediates and assembly. With relatively high fixed cost of captive offshoring in intermediate activities, most of the firms do not engage in FDI. Firms with relatively higher level of productivity may engage in FDI in assembly. And the most productive firms continue with their FDI in intermediates and assembly.

${ }^{25}$ Given that they focus on the effect of financial constraints and the risk of information leakage, the framework developed by Garcì-Vega and Huergo (2011) does not accommodate for the above differences.
} 
These findings may also support the learning path hypothesis developed by Maskell et al. (2007). Focusing on offshore outsourcing, they suggest that MNCs go through a sequential learning process from the offshoring of their productive tasks, which may be driven by cost minimization motives, to the offshoring of their innovative tasks, which may lead to differentiation advantages. The empirical evidence are so far inconclusive. While Maskell et al. (2007) find some empirical support for this proposition in a sample of Danish MNCs, Jabbour and Zuniga (2016) do not find enough support in a sample of French innovating firms. Though in this study I do not have access to longitudinal data, the cross-sectional evidence, reported in Section 3, suggest that the majority of MNCs with offshore innovation are also involved in the offshoring of their finished products and/or semi-finished products/components. ${ }^{26}$ This pattern is consistent with the above learning hypothesis.

\section{Conclusion}

Despite the estimated gains from global sourcing of innovative tasks (Ceci and Masciarelli 2010; Kotabe et al. 2007; Nieto and Rodrìguez 2011; Tabrizy 2015), only a small number of MNCs offshore their innovative activities. This is puzzling. In an attempt to provide an answer to this puzzle, I explore the superior productivity of the MNCs with offshore innovative activities compared to the other firms in the full sample and the sub-sample of MNCs. The results suggest that not only are those MNCs more productive than other firms in the full sample, but they are also significantly more productive than other MNCs. This superior productivity may explain why only a small number of MNCs partake in the offshoring of innovation.

Two caveats should be noted. First, the TFP measure in use is based on the residuals of a firm-specific Cobb-Douglas production function, which is estimated using the Levinsohn and Petrin (2003) approach. Thus, the dependent variable may suffer from measurement error. Unless the measurement error is well-behaved, the precision of the estimated parameter of interest can be a bit weak (Green 2012, pp. 97-99). That said, the estimated Levinsohn and Petrin (2003) productivity is among the most reliable TFP measures, which is widely used in empirical studies. Second, a shock to the error term in

\footnotetext{
${ }^{26}$ See Figure 1 for more details.
} 
the regression function, as given by Equation 1, not only affects the TFP measure, but it may also affect the likelihood that a firm partakes in global sourcing of innovative tasks. This endogeneity may also cause biased estimations. To address this endogeneity, however, one should either have access to a randomized trial or employ an exogenous variations to predict whether a firm offshores its innovative activities. That way, one can precisely estimate how the offshoring of innovative tasks may affect firms' productivity. In the absence of such trials and exogenous variations, this paper is among the first studies that look into the productivity requirements for offshoring different types of tasks. The results imply that those MNCs that belong to the highest two deciles of productivity are more likely to be able to partake in the offshoring of innovative tasks. This productivity requirement may explain why only a small number of firms gain from the global task distribution in innovative activities.

The key finding of this article has at least two policy implications for the countries that intend to host innovative activities. First, attracting foreign investments in R\&D, design, and engineering activities may require the participation of the most productive MNCs. As indicated in Section 3, these MNCs are likely to be larger in size. They are also likely to be among the leading firms in their industry (Jabbour and Zuniga 2016). Second, as discussed in Section 4.4, improvements in intellectual property protection at a given destination may lower the cost of offshoring innovative activities to that country. Also, given the cost of offhoring such activities, MNCs are more likely to internalize their offshore innovative activities via FDI (Tabrizy 2015). Thus, improvements in intellectual property rights and foreign ownership rules may increase the chance of a given country to become the destination for international innovative activities. 


\section{References}

Altomonte, Carlo, Tomasso Aquilante, and Gianmarco IP Ottaviano. 2012. The Triggers of Competitiveness: the EFIGE Cross-country Report. Brussels: Bruegel

Antràs, Pol. 2003. "Firms, Contracts, and Trade Structure." Quarterly Journal of Economics 118 (4): 1375-1418.

Antràs, Pol, and Elhanan Helpman. 2004. "Global Sourcing."Journal of Political Economy 112 (3): 552-580.

Barba Navaretti, Giorgio, Matteo Bugamelli, Fabiano Schivardi, Carlo Altomonte, Daniel Horgos, and Daniela Maggioni. 2011. The Global Operations of European Firms, Brussels: Bruegel.

Bardhan, Ashok Deo 2006. "Managing Globalization of R\&D: Organizing for Offshoring Innovation." Human Systems Management 25 (2) : 103-114.

Bernard, Andrew B., J. Bradford Jensen, Stephen J. Redding, and Peter K. Schott. 2012. "The Empirics of Firm Heterogeneity and International Trade." Annual Review of Economics 4: 283-313.

Bertrand, Olivier, and Michael J. Mol. 2013. "The Antecedents and Innovation Effects of Domestic and Offshore R\&D Outsourcing: The Contingent Impact of Cognitive Distance and Absorptive Capacity." Strategic Management Journal 34 (6) : 751-760.

Cantwell, John. 1995. "The Globalisation of Technology: What Remains of the Product Cycle Model?" Cambridge Journal of Economics 19: 155-155.

Cantwell, John, and Ram Mudambi. 2005. "MNE Competence-creating Subsidiary Mandates." Strategic Management Journal 26 (12) : 1109-1128.

Castellani, Davide, and Fabio Pieri. 2013. "R\&D Offshoring and the Productivity Growth of European Regions." Research Policy 42 (9): 1581-1594.

Ceci, Federica, and Francesca Masciarelli. 2010. "A Matter of Coherence: The Effects of Offshoring of Intangibles on Firm Performance." Industry and Innovation 17 (4): 373-392.

Crèpon, Bruno, Emmanuel Duguet, and Jacques Mairesse. 1998. "Research, Innovation And Productivity: An Econometric Analysis At The Firm Level." Economics of Innovation and New Technology 7 (2): 115-158.

D'Agostino, L.M., Laursen, K. and Santangelo, G.D. 2013. "The impact of R\&D Offshoring on the Home Knowledge Production of OECD Investing Regions." Journal of Economic Geography 13 (1) : 145-175.

Danguy, Jérôme. 2016. "Globalization of Innovation Production: A Patent-based Industry Analysis." Science and Public Policy (forthcoming).

Dunning, John H. 1994. "Multinational Enterprises and the Globalization of Innovatory Capacity." Research Policy 23 (1): 67-88.

Federico, Stefano. 2010. "Outsourcing Versus Integration at Home or Abroad and Firm Heterogeneity." Empirica 37(1), 47-63.

Feinberg, Susan E., and Anil K. Gupta. 2004. "Knowledge Spillovers and the Assignment of R\&D Responsibilities to Foreign Subsidiaries." Strategic Management Journal 25 (8-9): 823-845.

Fifarek, Brian J., and Francisco M. Veloso. 2010. "Offshoring and the Global Geography of Innovation." Journal of Economic Geography 10 (4): 559-578. 
Garcìa-Vega, Marìa, and Elena Huergo. 2011. "Determinants of International R\&D outsourcing: The Role of Trade." Review of Development Economics 15 (1): 93-107.

Granstrand, Ove., Lars Håkanson, and Sören Sjölander, S. (Eds.). 1992. Technology Management and International Business: Internationalisation of $R \& D$ and Technology. Wiley, Chichester.

Greene, William H. 2012. Econometric Analysis. Upper Saddle River, NJ: Pearson Prentice Hall.

Grimaldi, Rosa, Elisa Mattarelli, Andrea Prencipe, and Maximilian Von Zedtwitz. 2010. "Offshoring of Intangibles: Organizational and Strategic Issues." Industry and Innovation 17 (4): 331-336.

Grossman, Gene M., Elhanan Helpman, and Adam Szeidl. 2006. "Optimal Integration Strategies for the Multinational Firm." Journal of International Economics 70 (1): 216-238.

Helpman, E., Mark J. Melitz, and Stephen R. Yeaple. 2004. "Export versus FDI with Heterogeneous Firms." American Economic Review 94 (1): 300-316.

Jabbour, Liza, and Pluvia Zuniga. 2016. "The Outsourcing of Research and Development in Global Markets: Evidence from France." The World Economy 39 (3): 339-368.

Jensen, Peter D. Øberg, and Torben Pedersen. 2012. "Offshoring and International Competitiveness: Antecedents of Offshoring Advanced Tasks." Journal of the Academy of Marketing Science 40 (2): 313-328.

Kohler W., and Marcel Smolka. 2012. "Global Sourcing: Evidence from Spanish Firmlevel Data." In Quantitative Analysis of Newly Evolving Patterns of International Trade: Fragmentation, Offshoring of Activities, and Vertical Intra-industry Trade, edited by Stern, Robert M., World Scientific, Singapore

Kotabe, Masaaki, Denise Dunlap-Hinkler, Ronaldo Parente, and Harsh A. Mishra. 2007. "Determinants of Cross-national Knowledge Transfer and its Effect on Firm Innovation. Journal of International Business Studies 38 (2): 259-282.

Lall, Sanjaya. 1979. "The International Allocation of Research Activity by US Multinationals." Oxford Bulletin of Economics and Statistics 41 (4): 313-331.

Lai, Edwin L-C., Raymond Riezman, and Ping Wang. 2009. "Outsourcing of Innovation." Economic Theory 38 (3): 485-515.

Levinsohn, James, and Amil Petrin. 2003. "Estimating Production Functions Using Inputs to Control for Unobservables." The Review of Economic Studies 70 (2): 317341.

Lewin, Arie Y., Silvia Massini, and Carine Peeters. 2009. "Why Are Companies Offshoring Innovation? The Emerging Global Race for Talent." Journal of International Business Studies 40 (6): 901-925.

Martinez-Noya, Andrea, Esteban Garcia-Canal, and Mauro F. Guillen. 2012. "International R\&D Service Outsourcing by Technology-intensive Firms: Whether and Where?" Journal of International Management 18 (1): 18-37.

Maskell, Peter, Torben Pedersen, Bent Petersen, and Jens Dick-Nielsen. 2007. "Learning Paths to Offshore Outsourcing: From Cost Reduction to Knowledge Seeking." Industry and Innovation 14 (3): 239-257.

Melitz, Mark J. 2003. "The Impact of Trade on Intra-industry Reallocations and Aggregate Industry Productivity." Econometrica 71(6), 1695-1725. 
Narula, R., Zanfei, A., 2005. Globalization of Innovation: The Role of Multinational Enterprises. In The Oxford Hand-book of Innovation, edited by Fagerberg, Jan, David C. Mowery, and Nelson, Richard R. Oxford University Press, Oxford.

National Science Board. 2016. Science and Engineering Indicators 2016. Arlington, VA: National Science Foundation.

Nieto, Marì J., and Alicia Rodrìguez. 2011. "Offshoring of R\&D: Looking Abroad to Improve Innovation Performance." Journal of International Business Studies 42 (3): 345-361.

Pearce, Robert, and Satwinder Singh. 1992. Globalizing research and development. Springer.

Roberts, Peter W. 1999. "Product Innovation, Product-market Competition and Persistent Profitability in the U.S. Pharmaceutical Industry." Strategic Management Journal 20 (7): 655-670.

Ronstadt, R. C. 1977. Research and Development Abroad by US Multinationals, Praeger, New York.

Tabrizy, Saleh S. 2015. "An Empirical Assessment of the Effects of Trade in Innovative Tasks on Innovation Output." Southern Economic Journal 82 (1): 307-334.

Tamayo, Mery Patricia, and Elena Huergo. 2016. "Determinants of Internal and External R\&D Offshoring: Evidence from Spanish Firms." Industry and Innovation (forthcoming)

Tomiura, Eiichi. 2007. "Foreign Outsourcing, Exporting, and FDI: A Productivity Comparison at the Firm Level." Journal of International Economics 72(1): 113 - 127. 


\section{Tables}

Table 1: Number of firms involved in different types of off-shore activities, categorized based on their annual turnover in 2008.

\begin{tabular}{|c|c|c|c|}
\hline \multicolumn{4}{|c|}{ Number of firms who off-shore: } \\
\hline $\begin{array}{l}\text { Annual turnover in } \\
2008 \\
\text { (in million euros) }\end{array}$ & $\begin{array}{l}\text { the production of their } \\
\text { finished products }\end{array}$ & $\begin{array}{l}\text { the production of their } \\
\text { semi-finished } \\
\text { products/components }\end{array}$ & $\begin{array}{c}\text { their } \mathrm{R} \& \mathrm{D} \text {, design } \\
\text { and engineering } \\
\text { activities }\end{array}$ \\
\hline$<1$ & 3 & 4 & 1 \\
\hline $1-2$ & 18 & 10 & 1 \\
\hline $2-10$ & 145 & 115 & 21 \\
\hline $10-15$ & 48 & 39 & 3 \\
\hline $15-50$ & 115 & 76 & 26 \\
\hline $50-250$ & 86 & 49 & 24 \\
\hline$>250$ & 46 & 25 & 18 \\
\hline Total & $461^{\mathrm{a}}$ & 318 & $94^{b}$ \\
\hline Share of Large Firms ${ }^{c}$ & $53 \%$ & $47 \%$ & $72 \%$ \\
\hline
\end{tabular}

Note:

a) The turnover information is not available for 3 firms in this category.

b) The turnover information is not available for 1 firm in this category.

c) Firms with annual turnover greater than 15 million euros (2008) are identified as Large. 
Table 2: Full sample regression results

\begin{tabular}{|c|c|c|c|c|}
\hline & \multicolumn{4}{|c|}{ Estimation of the Parameters in Equation 1 (Full sample) } \\
\hline & \multicolumn{2}{|c|}{ OLS } & \multicolumn{2}{|c|}{ Ordered Probit } \\
\hline & TFP & TFP & TFP Deciles & TFP Deciles \\
\hline & $I-1$ & $I-2$ & II-1 & $I I-2$ \\
\hline \multirow[t]{2}{*}{ Ornd } & $0.126^{* *}$ & $0.125^{* *}$ & $0.200^{*}$ & $0.200^{*}$ \\
\hline & $(0.056)$ & $(0.056)$ & $(0.118)$ & $(0.118)$ \\
\hline \multirow[t]{2}{*}{ Exporter } & -0.016 & -0.016 & -0.042 & -0.043 \\
\hline & $(0.011)$ & $(0.011)$ & $(0.027)$ & $(0.027)$ \\
\hline \multirow[t]{2}{*}{ R\&D Performer } & $0.023^{* *}$ & $0.023^{* *}$ & $0.059^{* *}$ & $0.059^{* *}$ \\
\hline & $(0.011)$ & $(0.011)$ & $(0.026)$ & $(0.026)$ \\
\hline \multicolumn{5}{|l|}{ Annual turnover: } \\
\hline 1-2 million euros & $\begin{array}{c}0.124^{* * *} \\
(0.018)\end{array}$ & $\begin{array}{l}0.124^{* * *} \\
(0.018)\end{array}$ & $\begin{array}{c}0.342^{* * *} \\
(0.048)\end{array}$ & $\begin{array}{l}0.342^{* * *} \\
(0.048)\end{array}$ \\
\hline \multirow[t]{2}{*}{ 2-10 million euros } & $0.313^{* * *}$ & $0.314^{* * *}$ & $0.868^{* * *}$ & $0.870^{* * *}$ \\
\hline & $(0.018)$ & $(0.018)$ & $(0.046)$ & $(0.046)$ \\
\hline \multirow{2}{*}{ 10-15 million euros } & $0.488^{* * *}$ & $0.488^{* * *}$ & $1.343^{* * *}$ & $1.344^{* * *}$ \\
\hline & $(0.025)$ & $(0.025)$ & $(0.064)$ & $(0.065)$ \\
\hline \multirow[t]{2}{*}{ 15-50 million euros } & $0.578^{* * *}$ & $0.581^{* * *}$ & $1.616^{* * *}$ & $1.622^{* * *}$ \\
\hline & $(0.025)$ & $(0.025)$ & $(0.060)$ & $(0.060)$ \\
\hline \multirow[t]{2}{*}{$50-250$ million euros } & $0.852^{* * *}$ & $0.850^{* * *}$ & $2.227^{* * *}$ & $2.221^{* * *}$ \\
\hline & $(0.032)$ & $(0.032)$ & $(0.077)$ & $(0.078)$ \\
\hline \multirow[t]{2}{*}{ More than 250 million euros } & $1.053^{* * *}$ & $1.059^{* * *}$ & $2.755^{* * * *}$ & $2.770^{* * * *}$ \\
\hline & $(0.048)$ & $(0.049)$ & $(0.135)$ & $(0.136)$ \\
\hline Sector Dummies & Yes & Yes & Yes & Yes \\
\hline Country Dummies & Yes & Yes & Yes & Yes \\
\hline No. of observations & 7,426 & 7,376 & 7,426 & 7,376 \\
\hline & 0.289 & 0.288 & & \\
\hline Pseudo $\mathrm{R}^{2}$ & & & 0.087 & 0.087 \\
\hline
\end{tabular}

Notes: The control vector includes an export status dummy, a R\&D performance status dummy, ordinal size dummies, sector dummies, and country dummies. The regression function includes a constant term. Standard errors are reported in parentheses. Also, ${ }^{* * *} \mathrm{p}<0.01,{ }^{* *} \mathrm{p}<0.05$, and ${ }^{*} \mathrm{p}<0.10$. 
Table 3: Sub-sample regression results

\begin{tabular}{|c|c|c|c|c|}
\hline & \multicolumn{4}{|c|}{ Estimation of the Parameters in Equation 1 (Sub-sample) } \\
\hline & \multicolumn{2}{|c|}{ OLS } & \multicolumn{2}{|c|}{ Ordered Probit } \\
\hline & TFP & TFP & TFP Deciles & TFP Deciles \\
\hline & $I-1$ & $I-2$ & II-1 & $I I-2$ \\
\hline Ornd & $\begin{array}{c}0.200^{* * *} \\
(0.063)\end{array}$ & $\begin{array}{c}0.205^{* * *} \\
(0.064)\end{array}$ & $\begin{array}{l}0.330^{* *} \\
(0.135)\end{array}$ & $\begin{array}{l}0.348^{* *} \\
(0.136)\end{array}$ \\
\hline Exporter & $\begin{array}{c}0.012 \\
(0.051)\end{array}$ & $\begin{array}{c}0.004 \\
(0.053)\end{array}$ & $\begin{array}{c}0.051 \\
(0.094)\end{array}$ & $\begin{array}{c}0.024 \\
(0.099)\end{array}$ \\
\hline R\&D Performer & $\begin{array}{c}0.024 \\
(0.046)\end{array}$ & $\begin{array}{c}0.029 \\
(0.048)\end{array}$ & $\begin{array}{c}0.067 \\
(0.089)\end{array}$ & $\begin{array}{c}0.075 \\
(0.093)\end{array}$ \\
\hline Annual turnover: & & & & \\
\hline 1-2 million euros & $\begin{array}{c}0.191 \\
(0.170)\end{array}$ & $\begin{array}{c}0.175 \\
(0.170)\end{array}$ & $\begin{array}{c}0.665 \\
(0.639)\end{array}$ & $\begin{array}{c}0.608 \\
(0.640)\end{array}$ \\
\hline 2-10 million euros & $\begin{array}{l}0.397^{* * *} \\
(0.167)\end{array}$ & $\begin{array}{l}0.385^{* *} \\
(0.171)\end{array}$ & $\begin{array}{l}1.321^{* * *} \\
(0.637)\end{array}$ & $\begin{array}{l}1.321^{* * *} \\
(0.643)\end{array}$ \\
\hline 10-15 million euros & $\begin{array}{c}0.526^{* * *} \\
(0.175)\end{array}$ & $\begin{array}{c}0.511^{* * * *} \\
(0.180)\end{array}$ & $\begin{array}{l}1.740^{* * * *} \\
(0.647)\end{array}$ & $\begin{array}{l}1.728^{* * * *} \\
(0.655)\end{array}$ \\
\hline 15-50 million euros & $\begin{array}{c}0.572^{* * *} \\
(0.183)\end{array}$ & $\begin{array}{c}0.565^{* * *} \\
(0.188)\end{array}$ & $\begin{array}{l}1.983^{* * *} \\
(0.648)\end{array}$ & $\begin{array}{l}1.991^{* * *} \\
(0.654)\end{array}$ \\
\hline $50-250$ million euros & $\begin{array}{c}0.910^{* * *} \\
(0.176)\end{array}$ & $\begin{array}{c}0.880^{* * *} \\
(0.181)\end{array}$ & $\begin{array}{c}2.693^{* * *} \\
(0.658)\end{array}$ & $\begin{array}{c}2.648^{* * *} \\
(0.665)\end{array}$ \\
\hline More than 250 million euros & $\begin{array}{l}1.139^{* * *} \\
(0.180)\end{array}$ & $\begin{array}{l}1.139^{* * *} \\
(0.183)\end{array}$ & $\begin{array}{c}3.297^{* * *} \\
(0.665)\end{array}$ & $\begin{array}{c}3.320^{* * *} \\
(0.671)\end{array}$ \\
\hline Sector Dummies & Yes & Yes & Yes & Yes \\
\hline Country Dummies & Yes & Yes & Yes & Yes \\
\hline $\begin{array}{l}\text { No. of observations } \\
R^{2}\end{array}$ & $\begin{array}{c}630 \\
0.277\end{array}$ & $\begin{array}{c}580 \\
0.273\end{array}$ & 630 & 580 \\
\hline Pseudo $\mathrm{R}^{2}$ & & & 0.110 & 0.110 \\
\hline
\end{tabular}

Notes: The control vector includes an export status dummy, a R\&D performance status dummy, ordinal size dummies, sector dummies, and country dummies. The regression function includes a constant term. Standard errors are reported in parentheses. Also, ${ }^{* * *} \mathrm{p}<0.01,{ }^{* *} \mathrm{p}<0.05$, and $* \mathrm{p}<0.10$. 
Table 4: Sub-sample regression results

\begin{tabular}{lcc|cc}
\hline \multicolumn{4}{c}{ Estimation of the Parameters in Equation 2 (Sub-sample) } \\
\hline & \multicolumn{2}{c}{ OLS } & \multicolumn{2}{c}{ Ordered Probit } \\
\hline & TFP & TFP & TFP Deciles & TFP Deciles \\
\hline Ofin & $-0.192^{* * *}$ & $-0.196^{* * *}$ & $-0.318^{* *}$ & $-0.337^{* *}$ \\
& $(0.063)$ & $(0.0639)$ & $(0.136)$ & $(0.137)$ \\
Osem & $-0.240^{* *}$ & $-0.243^{* *}$ & $-0.378^{* *}$ & $-0.392^{* *}$ \\
& $(0.102)$ & $(0.102)$ & $(0.174)$ & $(0.176)$ \\
Other & $-0.183^{* *}$ & & -0.327 & \\
& $(0.089)$ & & $(0.203)$ & \\
Exporter & 0.011 & 0.00309 & 0.051 & 0.0236 \\
& $(0.051)$ & $(0.0532)$ & $(0.094)$ & $(0.0986)$ \\
R\&D Performer & 0.027 & 0.0316 & 0.070 & 0.0777 \\
& $(0.046)$ & $(0.0486)$ & $(0.090)$ & $(0.0937)$ \\
Annual turnover: & & & & \\
1-2 million euros & 0.177 & 0.163 & 0.647 & 0.591 \\
& $(0.170)$ & $(0.170)$ & $(0.641)$ & $(0.642)$ \\
2-10 million euros & $0.384^{* *}$ & $0.374^{* *}$ & $1.305^{* *}$ & $1.306^{* *}$ \\
10-15 million euros & $(0.168)$ & $(0.171)$ & $(0.639)$ & $(0.644)$ \\
& $0.514^{* * *}$ & $0.500^{* * *}$ & $1.724^{* * *}$ & $1.713^{* * *}$ \\
15-50 million euros & $(0.176)$ & $(0.181)$ & $(0.649)$ & $(0.656)$ \\
& $0.560^{* * *}$ & $0.553^{* * *}$ & $1.966^{* * *}$ & $1.976^{* * *}$ \\
50-250 million euros & $(0.187)$ & $(0.193)$ & $(0.650)$ & $(0.656)$ \\
& $0.893^{* * *}$ & $0.865^{* * *}$ & $2.672^{* * *}$ & $2.628^{* * *}$ \\
More than 250 million euros & $(0.179)$ & $(0.184)$ & $(0.660)$ & $(0.667)$ \\
& $1.122^{* * *}$ & $1.123^{* * *}$ & $3.277^{* * *}$ & $3.301^{* * *}$ \\
Sector Dummies & $(0.183)$ & $(0.187)$ & $(0.667)$ & $(0.673)$ \\
Country Dummies & Yes & Yes & Yes & Yes \\
No. of observations & Yes & Yes & Yes & Yes \\
$\mathrm{R}^{2}$ & 630 & 580 & 630 & 580 \\
Pseudo R ${ }^{2}$ & 0.278 & 0.273 & & \\
\hline Nos The & & & 0.110 & 0.110 \\
\hline
\end{tabular}

Notes: The control vector includes an export status dummy, a R\&D performance status dummy, ordinal size dummies, sector dummies, and country dummies. The regression function includes a constant term. Standard errors are reported in parentheses. Also, ${ }^{* * *} \mathrm{p}<0.01,{ }^{* *} \mathrm{p}<0.05$, and $* \mathrm{p}<0.10$. 


\section{Figure Captions}

Figure 1: Number of firms involved in different types of off-shore activities

Figure 2: Kernel density estimation for the distribution of TFP among MNCs

Figure 3: The estimated marginal effects for different productivity deciles based on the estimation results reported in Table 3, column $I-2$ 
Figure 1

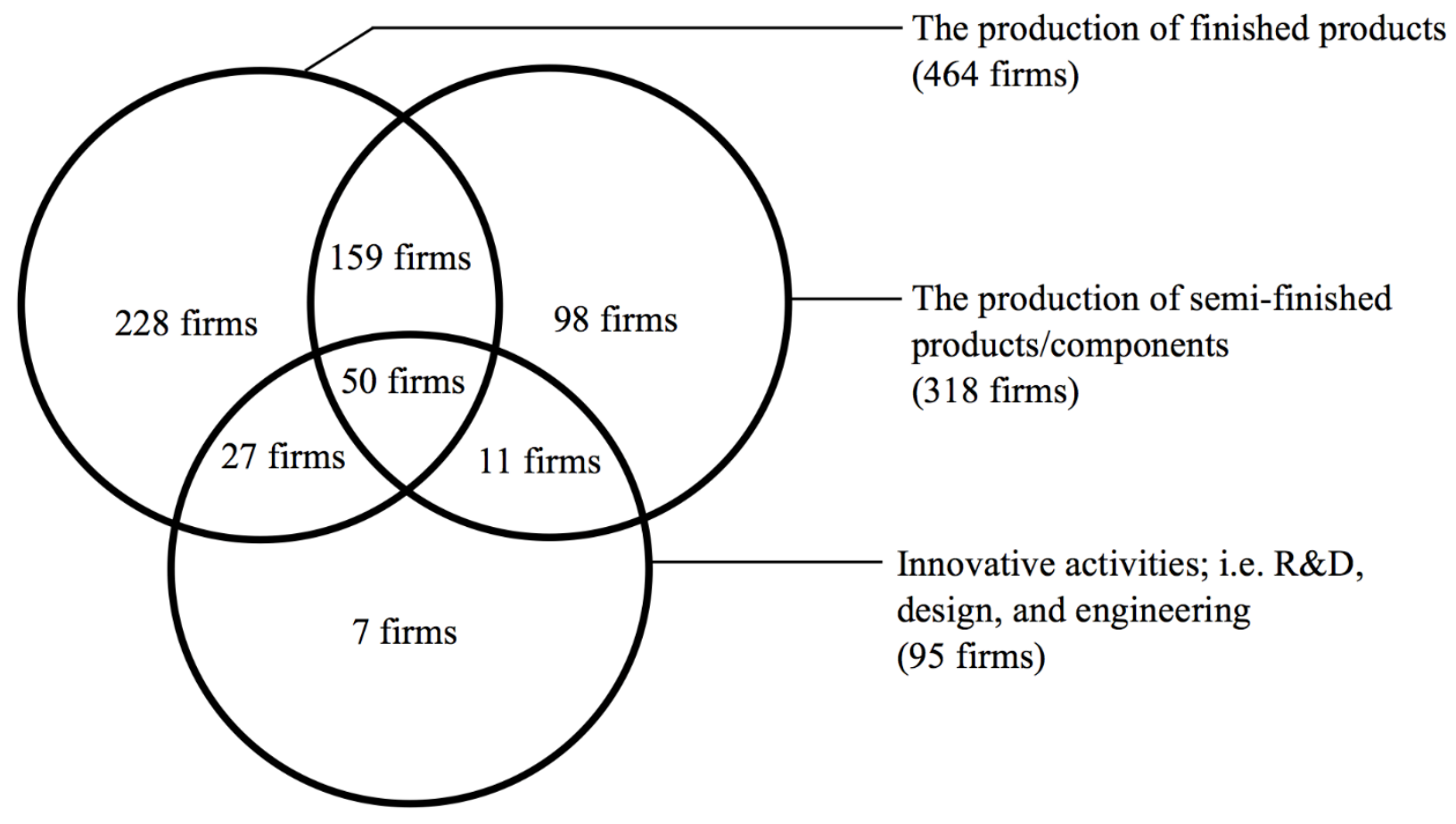


Figure 2

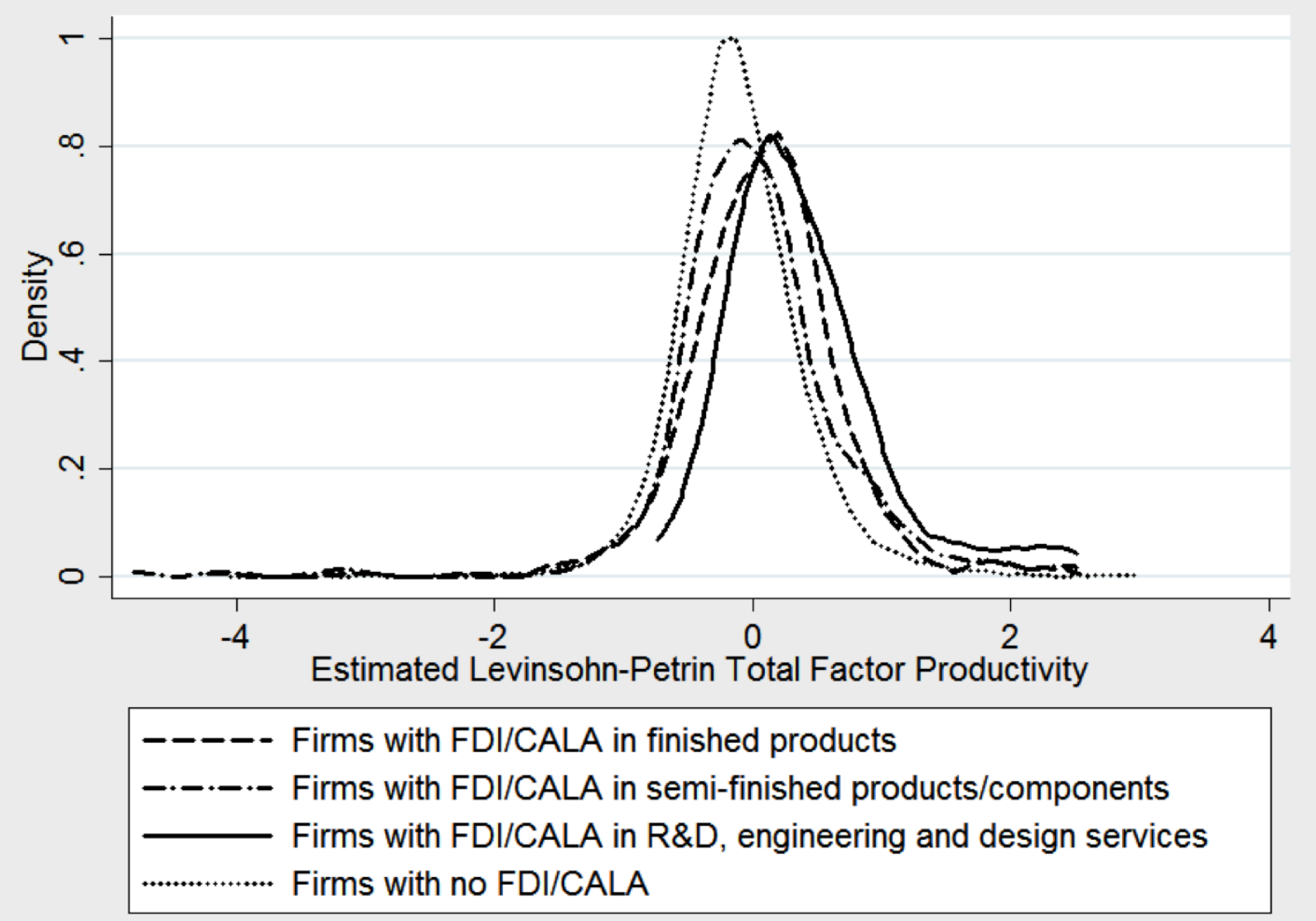

Note: FDI: Foreign Direct Investment; CALA: Contracts and Arms Length Agreements 


\section{Figure 3}

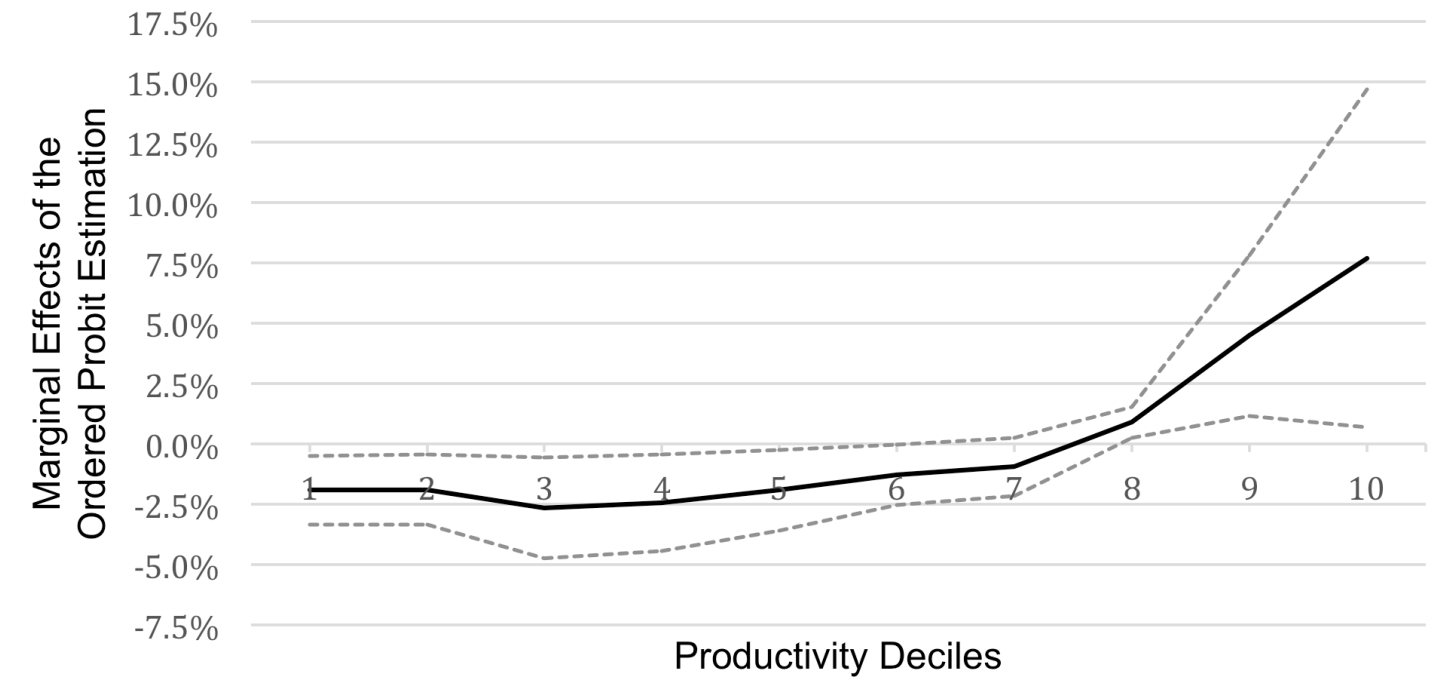

Note: The marginal effects are based on the estimation results reported in Table 3, column II-1. 